\title{
FEATURES OF STRUCTURAL ANALYSIS IN THE PROSE OF HEINRICH BÖLL
}

\author{
Lutfulla Tashkuvatovich Kholiyarov
}

Teacher, Uzbek State World Languages University, Uzbekistan

Abdushukur Alibaevich Rustamov

Teacher, Uzbek State World Languages University, Uzbekistan

\section{ABSTRACT}

Heinrich Theodor Böll - German writer (FRG), translator, Nobel Prize winner in literature. This article examines the history of his life and the stages of creativity, one of the largest artists of German literature of the twentieth century, who has always been in the center of attention of researchers and critics around the world. The subject of the research is the artistic features of the presentation of the concept of moral and aesthetic problems in the writer's works.

KEYWORDS:- Wealthy, maturity, published, significant, humanitarian, activity, genre, diverse, collection of stories, journalistic, revival, historical, dark years, the plot of the novel.

\section{INTRODUCTION}

Heinrich Böll was born on December 21, 1917 in Cologne in a Catholic family, Victor and Maria Böll. The family was wealthy enough, but during the economic crisis at the end of the 1920s, it went bankrupt and was forced to settle in the suburb of Cologne - Raderthal, where Heinrich attended a public school (1924-1928). Upon his family's return to Cologne, he studied at the humanitarian Greek-Latin grammar school (graduated in 1937).

Having received a certificate of maturity, he works as an apprentice seller in a second-hand bookstore, tries his hand at literature. In 1938, Böhl was mobilized for compulsory labor service, after which, in the summer of 1939, he entered the University of Cologne, but only a few months later he ended up in the Hitlerite army.
Böll's literary debut took place in 1947, when his story "The News" was published. The first significant work was the story "The Train Came on Time" (1949) - about German soldiers returning to their units after a short leave to the front to meet their death. The novel "Where have you been, Adam?" Brought Böll the real fame. (1951), whose protagonist, having gone through the entire war, deserts shortly before surrender and dies from a German shell on the threshold of his home. After the publication of this novel, Böll devoted himself entirely to literary activity.

The writer left a large and very diverse genre legacy: the novels And He Didn't Say a Single Word (1953), A House Without a Master (1954), Billiards at half past nine (1959), Through the Eyes of a Clown (1963) , "Group portrait with a lady" (1971), "The outraged honor of Katharina Blum, or How violence arises and what it can lead to" (1974), "The Caring Siege" (1979), 
CURRENT RESEARCH JOURNAL OF PEDAGOGICS 2(11): 64-70, November

2021 DOI: https://doi.org/10.37547/pedagogics-crjp-02-11-14

ISSN 2767-3278

(C)2021 Master Journals

\section{Crossref doi) 81 Google}

Accepted 25th November, 2021 \& Published 30 ${ }^{\text {th }}$ November, 2021

"Women against the Background of a River Landscape" (publ. 1985), "The Angel was Silent" (1992), etc .; collections of stories (including "A traveler, when you come to Spa ...", 1950; "City of familiar faces", 1955), stories ("Early Bread", 1955; "Unauthorized absence", 1964, etc.); plays and radio plays, journalistic and literary critical articles, essays, travel notes and diaries, translations. In 1972, Böll was awarded the Nobel Prize "for a work that combines a wide scope of reality with the high art of character creation and which has become a significant contribution to the revival of German literature."

The work of Heinrich Böll is largely devoted to the historical assessment of the Second World War and its consequences for the German people, mainly to the abyss of crime and immorality that fascism brought with it. Böll's main characters judge these dark years from the point of view of those humanistic principles that the author shares with them.

Such is the hero of the novel "Through the Eyes of a Clown" Hans Schnier. The novel, comparatively poor in external events and action, includes not only the views, opinions, judgments of the clown Shnir about the modern life immediately surrounding him, but also an assessment of everything he has seen and experienced before. Thus, Böll shows that a great moral determination and, above all, the inner honesty of each person in relation to himself and to those around him is necessary so that the bad past is completely outlived and ceases to affect the present. Hence the special development of the plot of the novel, its special structure: modern, "today's" events and impressions, one after another, no matter how small and insignificant they are, evoke painful and sorrowful memories of many cruel and terrible deeds, and the hero again and again returns to them, subjecting them to careful and merciless analysis.
At the same time, the "today's" action of the novel fits into one evening: after the failure of his tour, Hans Schnier returns to his hometown of Bonn and spends several hours sitting at home in his apartment, either talking on the phone with relatives, enemies and friends, or receiving someone from himself, and, finally, goes to the station to meet his ex-wife Marie, with whose departure from his life he cannot reconcile.

However, the events taking place at the present moment are only a series of external impulses, stimuli, thanks to which the author, through the lips of his hero, illuminates in the main outlines the path of his life; the characteristics of the relatives, friends and acquaintances of Hans Schnier are given, their behavior during the years of Hitler's domination is described, and how now many of them are trying to hide their tarnished past. Such are especially the parents of Shnir, the richest people in the city, with whom he has lost all spiritual connection. Finally, the history of his relationship with his beloved woman, who left him for the sake of a prominent Catholic figure, is also described.

Compositionally, Böll's novel is a complex fusion of various events and time slices, due to which a single, subjective-objective picture of reality is achieved, covering a significant period of German history. Building a first-person narrative makes the constant flipping from present to past and back again more than natural.

Heinrich Böll himself emphasized that the problem of time, the relationship of various temporal aspects (Ewigkeit, Augenblick, Jahrhundert) was always of great interest to him. At the same time, he seeks to reduce the direct development of the action of the novel to a minimum, at the expense of other narrative layers, in particular, such as reflection or memory. Ideally, the action time of the novel (that is, the present tense shown in the novel, from which the rays of reflection and memories 
CURRENT RESEARCH JOURNAL OF PEDAGOGICS 2(11): 64-70, November

2021 DOI: https://doi.org/10.37547/pedagogics-crjp-02-11-14

ISSN 2767-3278

(C)2021 Master Journals

\section{Crossref dof 81 Google}

Accepted 25th November, 2021 \& Published 30 ${ }^{\text {th }}$ November, 2021

constantly lead us into the past) should be brought to one minute.

The narrative thus proceeds in Böll's novel mainly in two time slices, it is two-layered. Moreover, if the first layer - directly occurring events in Shnir's life - is given as briefly as possible and at first glance is generally insignificant, then. the second layer, the past, quantitatively significantly exceeds the first and is the main one in terms of its intrinsic significance. The result of the novel is the moral assessment that arises as a result of comparing the historical "confrontation" of both time slices and the people who acted within their framework.

The comparative conciseness, the shortening of the plan of the present in relation to the plan of the past, stands out especially in the description of the telephone conversations that Shnir conducts that evening. These conversations are often more than laconic, but the memories and reflections that they evoke are several times greater in scope and significance. Here is the characteristic of the next interlocutor, and the constantly arising and growing commentary on all points of the topic touched upon, leading, again, to the past.

Indicative, for example, is Shnir's conversation with his mother [p. 39].

Already the decision of the question of who to call (Shnir writes out the phone numbers of his future interlocutors from the local phone book) is given as a motivation for a long detailed commentary on each of the named persons. So, among other names, Shnir mentions the name of his friend Monica Silva in order to embark on long explanations about their relationship, then the transition to the topic "Mari" follows, and again Shnir analyzes the reason for the departure of his wife from his wife to the Catholic Zupfner. The transition to the themes "brother Leo, mother, father", "sister Henrietta" is accompanied by a story about a sister who died through the fault of her parents during the days of Hitler's rule.

But Shnir found the phone number of his parents and, having called, waits at the device while the maid switches the phone [p. 38].

This is followed by a commentary detailing the difficulty of locating telephones in the Shnirov house. Naturally, Schnir himself does not need this commentary at all, but the reader does need it to get an idea, in particular, of the role played by Schnir's mother. as the spouse of a prominent money tycoon and as chairwoman of the "Central Committee of the Society for the Reconciliation of Racial Differences." The maid probably switched the phone much faster than the time that this comment took away from Shnir. But such is the convention introduced by Böll: all "today's" events are a matter of the moment, everything "yesterday" is a matter of an expanded narrative.

In addition, in the memories and reasoning of the hero of the novel, we constantly distinguish between two planes: comments designed for the reader's perception and are of a relatively business, informational nature, and internal commenting on events "for oneself", the purpose of which is to penetrate deep into the depicted (Bericht, Innerer Monolog) ...

While talking with his mother, Shnir simultaneously recollects about his sister Henrietta (for about a page of text), after which he asks his mother: "How is your father doing?" "How's Brother Leo?" The mother's answers are laconic, but after them - a new digression: Shnir is going to ask his mother about a certain Schnitzler [p. 41], one of the evil geniuses of their family, who is also responsible for the death of Henrietta's sister. But before asking about him, Shnier explains to us who this Schnitzler is and why we should ask about him (again, a digression of about one and a half pages). And 
CURRENT RESEARCH JOURNAL OF PEDAGOGICS 2(11): 64-70, November

2021 DOI: https://doi.org/10.37547/pedagogics-crjp-02-11-14

ISSN 2767-3278

(C)2021 Master Journals

\section{Crossref do) 8 Google}

Accepted 25 $5^{\text {th }}$ November, 2021 \& Published 30 ${ }^{\text {th }}$ November, 2021

only after that his question sounds: "Was machteigentlich Schnitzler?" [p. 42].

One might get the impression that Shnir's mother had been silently waiting at the telephone during all these long retreats. But in fact, Shnir's comments on the topics "Henrietta" and "Schnitzler" are held at a different level and only to us, the readers, they are presented in the form of a long tirade - for Shnir's mother, this time does not exist, as it were. This is how these two planes of time flow in different ways: directly occurring events - quickly, and the comments and memories generated by them unfold slowly, without violating, however, the once accepted ratio of the two moving streams of description of reality.

In addition, as already noted, many pieces of information of an informational and commentary nature do not just register the content of the hero's "stream of consciousness" in its raw, unprocessed form, but in some of its parts are, as it were, deliberately designed for a living listener-reader. Shnir does not just talk "to himself", but he also talks to us. Thus, Böll divides the commentary itself into factual and introspective parts. The genre "Ich-Erzählung", that is, narration from the first person, is used by the author in an extremely complicated form.

We have traced the relationship in Böll's novel of the elements of the present and the elements of the past, how they were distributed within one chapter. It is obvious that these two time slices are not just adjacent, but extremely closely intertwined with each other, forming, as it were, a double reality, a double plot created on the basis of two parallel series of events. The combination of these two sections is directly reflected in the structure of the primary compositional and narrative units - paragraphs.

The implementation of the task would be possible either by alternating paragraphs entirely devoted to one or the other time slice, or by combining both time slices in one paragraph in their various combinations. It is on the second of these paths that Böll follows. Moreover, even the structure of a single sentence in Böll is capable of responding to such compositional diversity.

Without dwelling on this issue, which is not directly related to the topic of this article, we. however, we can note that such a method of depicting life through the closest interlacing and collision of two "realities", two temporary layers, consciously chosen by the writer, was reflected in the construction of the paragraph. At one point in the paragraph, rather at its beginning, the links of "current reality" find their place, in another - links dedicated to the image of the past (mixed paragraph structure).

Let's move on to specific examples. In the excerpt from the novel quoted below, there is a telephone conversation between Hans Schnier and his brother Leo. Leo invites his brother to provide him with a small amount of money, followed by a comment that takes up a significant part of the paragraph. At the same time, in the middle of the paragraph, in terms of returning to the ongoing telephone conversation, a brief exchange of remarks appears again, accompanied by a new comment. Thus, in the paragraph under consideration, the replacement of the immediate image of the present moment with an explanatory commentary, leading to the past, occurs twice.

„Hans?" sagte Leo.

„Ja“, sagte ich, „schön, dass du kommst." Er schwieg, hüstelte, ich hatte seine Stimme nicht sofort erkannt Er sagte: „Ich habe das Geld für dich." Das Geld klang seltsam. Leo hat I überhaupt seltsame Vorstellungen von Geld. Er: ist fast vollkommen bedürfnislos, raucht nicht, trinkt nicht, liest keine Abendzeitungen und geht nur ins Kino, wenn mindestens fünf Personen, denen er vollkommen vertraut, ihm den Film als 
CURRENT RESEARCH JOURNAL OF PEDAGOGICS 2(11): 64-70, November

2021 DOI: https://doi.org/10.37547/pedagogics-crjp-02-11-14

ISSN 2767-3278

(C)2021 Master Journals

\section{Crossref doi) 81 Google}

Accepted 25th November, 2021 \& Published 30 ${ }^{\text {th }}$ November, 2021

sehenswert empfohlen haben; das geschieht alle zwei-drei Jahre. Er geht lieber zu Fuß als mit der Bahn zu fahren. Als er das Geld sagte, sank meine Stimmung sofort wieder. Wenn er gesagt hätte, etwas Geld, so hätte ich gewusst, dass es zwei bis drei Mark wären. Ich schluckte an meiner Angst und fragte Heisen „Wieviel?" — „Oh“, sagte er, „sechs Mark und siebzig Pfennige." Das war für ihn eine Menge, ich glaube, für das, was man persönliche Bedürfnisse nennt, langte das für ihn auf zwei Jahre: hin und wieder eine Bahnsteigkarte, eine Rolle Pfefferminz, ein Groschen für einen Bettler, er brauchte ja nicht einmal Streichhölzer, und wenn er sich einmal eine Schachtel kaufte, um sie für „Vorgesetzte“, denen er Feuer geben musste, griffbereit $\mathrm{zu}$ haben, dann kam er ein Jahr damit aus, und selbst wenn er sie ein Jahr lang mit sich herumtrug, sah sie noch wie neu aus. Natürlich musste er hin und wieder zum Friseur gehen, aber das nahm er sicher vom "Studienkonto“, dass Vater ihm eingerichtet hatte. Früher hatte er manchmal Geld für Konzertkarten ausgegeben, aber meistens hatte er von Mutter deren Freikarten bekommen. Reiche Leute bekommen ja viel mehr geschenkt als arme, und was sie kaufen müssen, bekommen sie meistens billiger, Mutter hatte einen ganzen Katalog vom Grossisten: ich hätte ihr zugetraut, dass sie sogar Briefmarken billiger bekam. Sechs Mark siebzig - das war für Leo eine respektable Summe. Für mich auch, im Augenblick - aber er wusste wahrscheinlich noch nicht, dass ich — wie wir es zu Hause nannten - „im Moment ohne Einnahmen" war. [p. 288-289]

Consider the alternation of grammatical tenses within this paragraph. The events of the present tense, shown in their coherent sequence, are given in the past narrative (preterite), while in the transition to the commentary (a generalizing description of Leo's brother is given), a natural transition to the present takes place (Leo hat überhauptseltsameVorstellungen von Geld).
After the second group of remarks, such a transition to the present time does not occur immediately: here the summarizing characteristic is somewhat diluted with a significant number of real facts from the past, also data in the preterite, but later, with the transition to a generalizing maxim, the present tense reappears (ReicheLeutebekommen ja vielmehrgeschenktalsarme ...).

Here is the first part of another paragraph, which describes the consequences of an unpleasant conversation between Hans Schnier and his father.

Mein Vater litt, es war offensichtlich und erschütternd. Er wandte sich zum Fenster hin, zog sein Taschentuch und trocknete sich ein paar Tränen. Ich hatte das noch nie gesehen, daß er weinte und sein. Taschentuch richtig benutzte. Er bekam jeden Morgen zwei frische Taschentücher herausgelegt und warf sie abends ein bißchen verknautscht, aber nicht merklich angeschmutzt in den Wäschepuff in seinem Badezimmer. Es hatte Zeiten gegeben, in denen meine Mutter aus Sparsamkeit, Waschmittel knapp waren. lange Diskussionen mit ihm darüber führte, ob er nicht die Taschentücher wenigstens zwei oder drei Tage mit sich herumtragen könne. „Du trägst sie ja doch nur mit dir herum, und richtig schmutzig sind sie nie - und es gibt doch Verpflichtungen der Volksgemeinschaft gegenüber." Sie spielte damit auf „Kampf dem Verderb“ und "Groschengrab" an. Aber Vater war - das einzige Mal, soweit ich mich erinnern konnte energisch geworden und hatte darauf bestanden, morgens seine beiden frischen Taschentücher zu bekommen. Ich hatte noch nie ein Tröpfchen oder Stäubchen, irgendetwas, was Naseputzen notwendig gemacht hätte, an ihm gesehen. Jetzt stand er am Fenster und trocknete nicht nur Tränen, wischte sogar so etwas Ordinäres wie Schweiß von der Oberlippe. Ich ging raus in die Küche, weil er immer noch weinte, ich hörte ihn sogar ein bisschen schluchzen. Es gibt nur 
CURRENT RESEARCH JOURNAL OF PEDAGOGICS 2(11): 64-70, November

2021 DOI: https://doi.org/10.37547/pedagogics-crjp-02-11-14

ISSN 2767-3278

(C)2021 Master Journals

\section{Crossref do) 8 Google}

Accepted 25th November, 2021 \& Published 30 ${ }^{\text {th }}$ November, 2021

wenige Menschen, die man gern dabei hat, wenn man weint... [p. 202-203]

The commentary begins with a pluperfect (Ichhatte das nochniegesehen ...), as the generalization goes back to the distant past. A further transition to the preterite means a closer past, reaching up to the present time (Erbekamjeden Morgen ...), and a return to the pluperfect (EshatteZeitengegeben ...) again marks a departure into the more distant past. It is interesting to note that the transition to a coherent narrative of the present moment is clearly expressed by a return to the preterite (Jetzt stand er am Fenster ...). Thus, preterite performs at least two functions in Böll's novel and is used: 1) in a coherent narration about successive events in the past (the traditional use of preterite); 2) when describing the events that have just happened, which, however, managed to find coherence and consistency in the consciousness of the hero-narrator (Kontinuum and thereby somewhat move away from the moment of speech.

Consider also building a closed paragraph form. Its "closeness" is not so much semantic (since it ends with a question of one of the interlocutors, playing the role of a correlate for the subsequent answer in the next paragraph), as compositional: the beginning and ending of it are the replies of the interlocutors from the time slice of the present moment, and its middle part is filled with a comment - a description of the room in which the conversation is taking place.

Na gut”, sagte er. „wie du-willst“ Er wirkte auf eine unangemessene Weise' gekränkt. Er groß: Rudel ein, hielt mir sein Zigarettenetui) hin, ich nahm eine, er gab mir Feuer, wir rauchten. Er tat mir leid. Ich hatte ihn mit meinem Teller Bohnen wahrscheinlich ganz aus dem Konzept gebracht Er hatte sicher damit gerechnet, bei mir das vorzufinden, was er sich unter Boheme vorstellt: ein gekonntes Durcheinander und allerlei
Modernes an Decke und Wänden, aber die Wohnung ist auf eine zufällige Art stillos eingerichtet fast spießig, und ich merkte, dass ihn das bedrückte. Die Anrichte hatten wir nach einem Katalog gekauft, die Bilder an den Wänden waren lauter Drucke, nur zwei gegenstandlose darunter, einzig hübsch zwei Aquarelle von Monika, Silvs, die über der Kommode hängen: Rheinlandschaft III und Rheinlandschaft IV, dunkelgraue Töne mit kaum sichtbaren weißen Spuren. Die paar hübsche Sachen, die wir haben, Stühle, ein paar Vasen und der Teewagen in der Ecke, hat Marie gekauft. Mein Vater ist ein Mensch, der Atmosphäre braucht, und die Atmosphäre in unserer Wohnung machte ihn nervös und stumm. „Hat Mutter dir erzählt, dass ich hier bin?" fragte ich schließlich, als wir die zweite Zigarette ansteckten, ohne ein Wort gesprochen zu haben. [p.176]

In the above paragraph, we see an interesting picture of the changing grammatical tenses. At the beginning of the paragraph, the father's visit is described (it will be repeated to the words Er tat mirleid) ... Then Hans Schnier's comments begin. His reflections on how he could offend his father are given, of course, in the pluperfect. However, already in the middle of the second sentence, following Er tat mirleid, the description of Shnir's apartment in its current state is given in a presentation (... aber die Wohnungistauteinezufällige Art stilloseingerichtet ...). With each return to the events of the present moment, there is a return to the preterite. The memory of a long past time is given in the pluperfect (Die AnrichtehattenwirnacheinemKataloggekauft ...), after which the return to the preterite is perceived again as a story about today (... die Bilderap den WändenwarenlauterDrucke ...) ... It is interesting to note that here one more shade of a more "near" present time appears within the present day, and we perceive it as coinciding with the moment of the utterance. This present is 
CURRENT RESEARCH JOURNAL OF PEDAGOGICS 2(11): 64-70, November

2021 DOI: https://doi.org/10.37547/pedagogics-crjp-02-11-14

ISSN 2767-3278

(C)2021 Master Journals

Crossref dof 81 Google

Accepted 25th November, 2021 \& Published 30th November, 2021

expressed not in the preterite, but in the present, but what happened before is given in the perfection correlated with it (Die paarhübschenSachen, die wirhaben, hat Marie gekauft). The generalized description of the father is again given in the presentation, and by the end of the paragraph, when describing the events that have just happened, there is a return to the sequential narrative preterite (Mein Vateristein Mensch, der Atmosphärebraucht, und die At-mosphäre in unsererWohnungmachteihnnervös) ...

\section{REFERENCES}

1. Belle G. Through the eyes of a clown. Per. R. Wright-Kovaleva // Belle G. Favorites. Decree ed. p.421-560.

2. Belle G. Group portrait with a lady. Per. L. Chernoy - // Novels by G. Bell. B 2 kn. Book .: - Chisinau: Lumkna, 1987.- 446 p.

3. Böll G. Women on the banks of the Rhine: [novel] / G. Böll. - M .: International Relations, 1989 .-- 176 p.

4. Böll G. Selected works / G. Böll; [lane. with him. S. Fridlyand]. - M .: Panorama, 1994 .-$496 \mathrm{p}$.

5. Motyleva T.L. Heinrich Böll: Prose of different years // G. Böll. Unauthorized absence: Novels, stories. Minsk, 1989.

6. Böll H. DasBrot der frühenJahre: [erzählung] / H. Böll. - München: DeutscherTaschenbuchVerlag, 2007 .-- 112 p.

7. Böll H. Frankfurter Vorlesungen / H. Böll. München: DeutscherTaschenbuchVerlag, 1968 .- 121 p.

8. Boll K. Ansichteneines Clowns. Köln-Berlin, 1968. 303 p.

9. Boll H. Gruppenbildmit Dame. Köln, 1974. 34 p.
10. Schröter K. Heinrich Boll in Selbstzeugnissen und Bilddokumenten. Hamburg, 1982.-152 p. 